\title{
THE QUALITATIVE ANALYSIS OF THE EFFECTIVE COMPONENTS OF SUSTAINABLE ARCHITECTURE IN THE DESIGN OF HIGH-RISE BUILDINGS IN ORDER TO REDUCE ENERGY CONSUMPTION IN TABRIZ
}

\author{
Yaser Narimanpour Maleki ${ }^{1}$, Shabnam Namdar Akbari², Nader Ghaemi², \\ Somayyeh Omranifar ${ }^{2}$
}

${ }^{1}$ Young Researchers and Elite Club, Tabriz Branch, Islamic Azad University, Tabriz, Iran

${ }^{2}$ Department of Architecture, Tabriz Branch, Islamic Azad University Tabriz, Iran

\author{
Research Article \\ PII: S238315532000003-9 \\ Received: 15 May, 2020 \\ Revised: 12 June, 2020 \\ Published: 15 June, 2020
}

${ }^{\star}$ Corresponding author's E-mail:

\begin{abstract}
The issue of energy in our country has not received considerable attention for years, however, in recent years, designers and planners sought to focus on the subject of the optimization of energy consumption in one of the major centers of energy consumption, that is building, due to the high cost of energy consumption and the concern about the depletion of these energy resources and the pollution arising from consuming these fuels. Meanwhile, tall buildings consume a large portion of nonrenewable energy resources. Due to the construction of high-rise buildings, growing urban population, and limited proper land, designers should seek to reduce its negative environmental effects instead of rejecting it. Therefore, it is necessary to pay attention to sustainable architectural strategies in the process of designing and the exploitation stage of these buildings because of the accumulation of users at a limited level the significant use of energy resources in tall buildings. This paper attempts to analyze the effective elements in sustainable architecture in the design of high-rise buildings in Tabriz to reduce energy consumption. This study is of quantitative nature and data was collected using archive or library study. The findings of this research highlight that observing the effective components of sustainable architecture in the design of towering buildings contributes to saving energy consumption for space heating by $66 \%$, and saving energy consumption for space cooling by $37.5 \%$.
\end{abstract}

KEYWORDS: Sustainability, Climate, Energy Consumption, High-Rise Buildings

\section{INTRODUCTION}

Considering the statistics related to the high rate of urbanization all over the world, especially in developing countries as well as Iran, it could be estimated that, in the next 20 years, about $60 \%$ of the world's population will live in cities.

This number in Iran has been predicted to be $70 \%$. The addition of each household to the urban population has different consequences, the most important of which is the provision of housing [1]. The issue of high-rise buildings is also at the beginning of a great transformation. Today, the crisis of housing quality has overcome the issue of quantity crisis, which is due to the adoption of policies to solve the problem of housing like constructing buildings "as fast as possible", "as small as possible", and "as cheap as possible", that are high on the agenda [2].

On the other hand, in our country, energy consumption in buildings amounts to $40 \%$ of total consumed energy. For the meantime, among the components of energy consumption in the building, the heating systems of buildings that mainly use fossil fuels, are among the major consumers of energy, so that $70 \%$ percent of natural gas consumed in buildings is spent on heating [3]. Also, in large cities, 30\% percent of air pollution is generated from buildings. So, our environment is being harmed and is moving in an unpleasant direction [4].

On sustainable development and, of course, sustainable architecture, it has become clear that every building must interact with its natural environment. The controversial and considerable part of this issue is how to establish the interaction and also the type of measures considered. Given the cold and dry climate Tabriz, designing buildings should be done in a way that we can use natural energies to the maximum, and thus we can direct the criteria of a building towards sustainability [5]. This study, first, discussed the issue of sustainable architecture and its principles. Then, the climatic 
design strategies of high-rise buildings in accordance with the cold and mountainous climate of Tabriz city, and the impact of these strategies on reducing fossil fuel consumption will be studied and analyzed. The aim of this study is to explain the design models of large buildings consistent with the cold and mountainous climate of Tabriz to reduce energy consumption.

Hypothesis: there is a feature in sustainable architecture that has led to reduced energy consumption in massive buildings.

Research question: How and using what strategies will architectures reduce energy consumption in high-rise buildings?

\section{MATERIAL AND METHODS}

To create a cohesive foundation, data in this quantitative research has been gathered based on library study and field research and this study deals with analyzing effective components of sustainable architecture in designing high-rise buildings to reduce energy consumption in Tabriz.

\section{Sustainable architecture}

Today, the issue of sustainable development is considered to be one of the most fascinating and common discussions at the international level. The extensive and scholarly discussion on this topic led to the opening of The United Nations Conference on Sustainable Development, also known as Earth Summit in Rio de Janeiro, Brazil.

This conference was later called Rio Summit in which a resolution was issued to offer strategies for the sustainable development of countries around the world [5]. This is the most important definition of sustainable design presented at the Rio Summit: sustainable design is a kind of design that aims to fill the current needs without damaging the resources of future generations. In sustainable design, the socioeconomical sustainability should be considered just like the degree of energy consumption and the environmental effect of buildings and cities [6].

The principles of sustainable architecture

To achieve sustainable development, the following strategies and principles should be observed:

1. Using and sustaining the consumption of renewable resources (sun and wind).
2. Optimizing the use of resources and minimizing the use of natural resources in a proportion that is less than their natural growth.

3. Minimum production of waste and pollution that can be absorbed on a scale and capacity ranging from the environment to world.

4. Providing basic human and Social needs and creating a healthy environment for future generations [7].

\section{Housing}

The great land of Iran is one of the few countries that has provided a unique type of architectural culture to the world architecture during its history. Important cultural and geographical features of Iran have made for a great variety in its architecture [8]. The formation of housing is subject to cultural, climatic, economical, and subsistence factors and conditions [9].

Studying the history of housing, it could be found out that human beings have inevitably adapted themselves and their living space to climatic and cultural conditions. It could be found out that three important factors constituting the primary man-made shelters include the climate in which they lived, the type of material that they had access to, and predicting and developing methods to prevent dangers that might threaten them [10].

In the second meeting on human housing which took place in Istanbul, favourable housing has been defined as follows: desirable shelter does not simply mean a roof over the head of each person, rather it means desirable comfort, desirable space, physical access and greater security, ownership security, stability, construct durability, proper lightening, ventilation, and heating system as well as proper basic infrastructures such as water supply, hygiene, good environmental quality, and suitable place in terms of work and basic facilities all of which need to be provided according to the people's affordability [11].

\section{Climatic design}

The term 'implementing climatic design' is used to refer to specific construction techniques the aim of which is to reduce heating and cooling costs using natural energy flows to create comfort conditions in buildings. Climatic design is a method that is used to reduce the overall energy costs of a building and creates better comfort conditions for buildings [12].

Table 1. The table of literature review in order of historical sequence 


\begin{tabular}{|c|c|c|c|}
\hline Time & Author(s) & $\begin{array}{l}\text { The title of research } \\
\text { work }\end{array}$ & Results \\
\hline 2004 & $\begin{array}{l}\text { Hariri, Rezai et } \\
\text { al. [13] }\end{array}$ & $\begin{array}{l}\text { The national Building } \\
\text { regulations of Iran. } \\
\text { Discussion }\end{array}$ & $\begin{array}{l}\text { In addition to the location of building, it is necessary to observe } \\
\text { other factors such as the installation of controlled entrances, the } \\
\text { use of rough textures and dark colors to cover the exterior } \\
\text { surface of buildings and reducing the area of opening surfaces. }\end{array}$ \\
\hline 1999 & $\begin{array}{l}\text { Pourdeyhami, } \\
\text { S. [14] }\end{array}$ & $\begin{array}{l}\text { Construction in } \\
\text { Accordance } \quad \text { with } \\
\text { Climate }\end{array}$ & $\begin{array}{l}\text { The formation and direction of building shell should be in such a } \\
\text { way that it can absorb maximum radiation in winter. }\end{array}$ \\
\hline 2000 & $\begin{array}{l}\text { Nagizadeh, M. } \\
{[15]}\end{array}$ & $\begin{array}{l}\text { The qualitative } \\
\text { features of desirable } \\
\text { building (the basics } \\
\text { of design the ways to } \\
\text { achieve it) }\end{array}$ & $\begin{array}{l}\text { Desirable and proper housing must have these characteristics: } \\
\text { the possibility of interacting with environment: buildings should } \\
\text { be designed so that the need for artificial regulators of } \\
\text { environmental conditions be reduced to the minimum. }\end{array}$ \\
\hline 2014 & $\begin{array}{l}\text { Golabchi, M. } \\
{[16]}\end{array}$ & $\begin{array}{l}\text { The Basics of } \\
\text { Designing High-rise } \\
\text { Buildings }\end{array}$ & $\begin{array}{l}\text { High-rise buildings consume large amount of non-renewable } \\
\text { energy resources and are regarded as one of the most non- } \\
\text { ecological buildings. Given the need to construct towering } \\
\text { buildings, designers should seek to reduce its negative } \\
\text { environmental effects instead of ruling it out. }\end{array}$ \\
\hline
\end{tabular}

The analysis and processing research was from the point of view of author.

\section{Tabriz climate}

Tabriz is the center of Eastern Azerbaijan province which is located at approximately 46 degrees 25 minutes east longitude, 38 degrees 2 minutes north latitude from Greenwich Meridian. The elevation of Tabriz is $1340 \mathrm{~m}$ [17]. Among the climatic characteristics of Tabriz, we can refer to its bitter and long winters, and for several months of the year, the earth is covered with ice and snow. Rainfall is low in summer due to mountain range in western Iran, which, as a barrier, prevents Mediterranean air from entering Iran and retains moisture in its hillside. Rainfall in winters is mostly in the form of snow, and in general, in the region, short spring separates winter and summer from each other. Examining temperature information in Tabriz, it could be found that $62 \%$ of the time the weather is cold and very cold, and $17 \%$ of the time the weather is hot and basically the weather is not very hot, and $21 \%$ of the time the weather is mild [18]. Figure 1 shows the range of need for shade and sun in different months of the year in Tabriz. This figure supports that buildings in Tabriz need shade in the hours of the day in the months of June, July, August, and September, and need sun in the other months of the year.

Climatic design measures for high-rise buildings in Tabriz to reduce energy consumption

Climatic design measures for housing in cold climate includes the following: 1) Landscape design arrangements; 2) Building design arrangements; 3)
Building shell design arrangements; 4) Mechanical heating system.

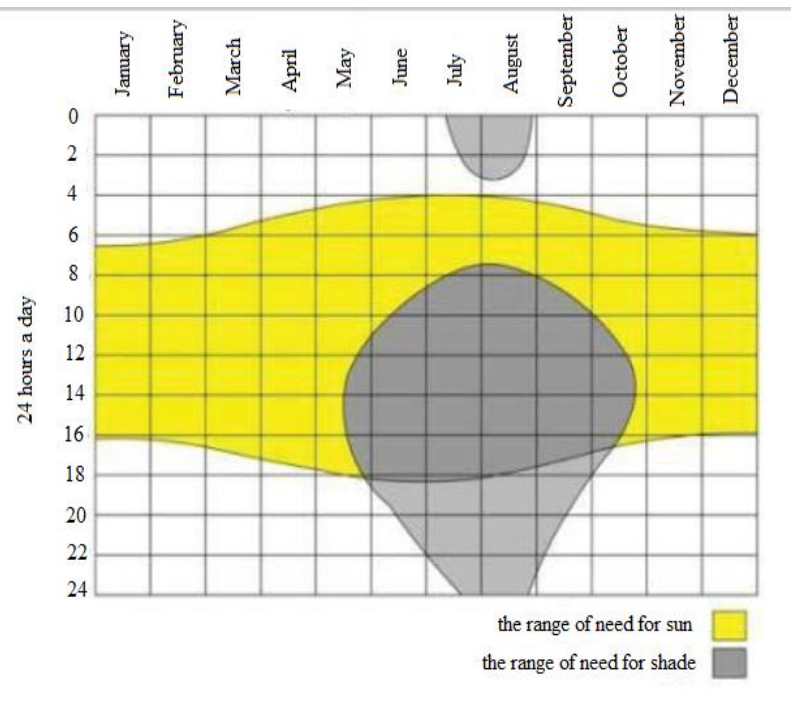

Figure 1. The calendar of need for shade and sun [24].

\section{Landscape design arrangements}

Landscaping using trees and plants can reduce energy consumption for heating and cooling. In this method, by the shading of trees, the ability of trees to direct the flow of air as well as by the evaporation of plants, inactive and cooling can be created. Using careful landscaping and design ideas, we can be influential in the optimization of energy consumption and energy storage, especially at the height of summer and winter. Studies on the analysis of the energy consumption of households 
suggest that landscaping helped reduce energy consumption by $25 \%$ for heating, and by $50 \%$ for cooling [19]. Landscape design measures in winter and summer have been shown in Table 3 .

Table 2. Landscape design measures in winter and summer [19].

\begin{tabular}{|l|l|}
\hline $\begin{array}{l}\text { Landscape design } \\
\text { measures }\end{array}$ & Description \\
\hline $\begin{array}{l}\text { Using plants for } \\
\text { protecting against } \\
\text { winter wind }\end{array}$ & $\begin{array}{l}\text { Evergreen trees in the northern and } \\
\text { eastern sides of the building slow } \\
\text { down the wind and create a layer of } \\
\text { thermal insulation }\end{array}$ \\
\hline $\begin{array}{l}\text { Using plants to create } \\
\text { shade in summer }\end{array}$ & $\begin{array}{l}\text { Trees that shed their leaves, reduce } \\
\text { indoor temperature in summer and } \\
\text { increase it in winter on the south } \\
\text { and southwest fronts of the } \\
\text { building. }\end{array}$ \\
\hline
\end{tabular}

\section{Building design measures}

\section{Placing building deep in the ground}

Harsh weather conditions in the basement can be significantly stabilized and mitigated, and this can barely be considered as an advantage for underground buildings. In fact, below the depth of 1.5 to $2 \mathrm{ft}$ (45 to $61 \mathrm{~cm}$ ), not much of daily temperature changes are noticeable [12]. With more building coverage by land, the building can be protected from the air. In surface structures, up to $35 \%$ of heat loss can often be due to air penetration [20].

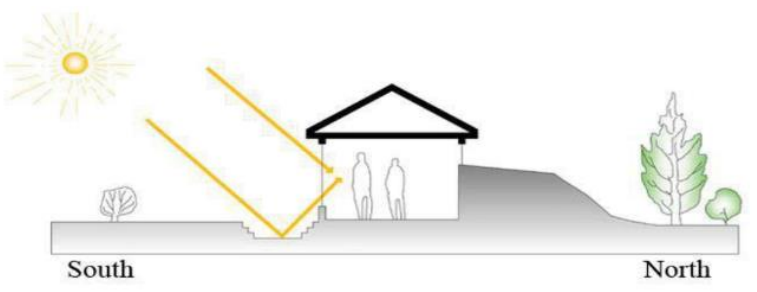

Figure. 2. More coverage of building by land [21].

Semi-protected areas outside the building

Patios, porches, and enclosed areas outside the house contribute to the comfort of the interior space and function as a private space. The protrusion in front of the roof and porches in summer casts a shadow over walls, openings, and the area around the building, and this helps keep the air temperature outside the building down. These outdoor spaces are also beneficial in winter. Buildings can be designed to create a series of solar boxes next to the building. These boxes can keep the air around the house warm by using sun's heat which will not only increase the length of time the building's outdoor space is used, but also will help create a warmer environment, and so the building's heat loss will be reduced. Plants, outdoor walls and even greenhouse can be used for this purpose [12]. These semi-protected areas outside the building reduce energy consumption for heating spaces by $20 \%$ [22].

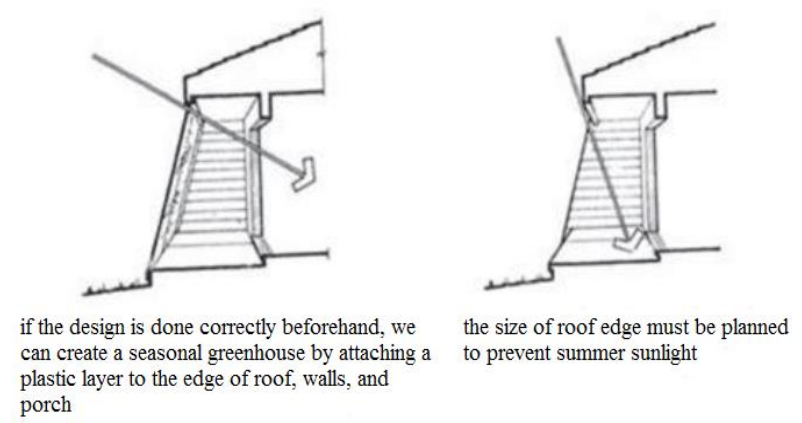

Figure 3. semi-protected areas outside the building - preventing summer sunlight and keeping sun heat in winter [12].

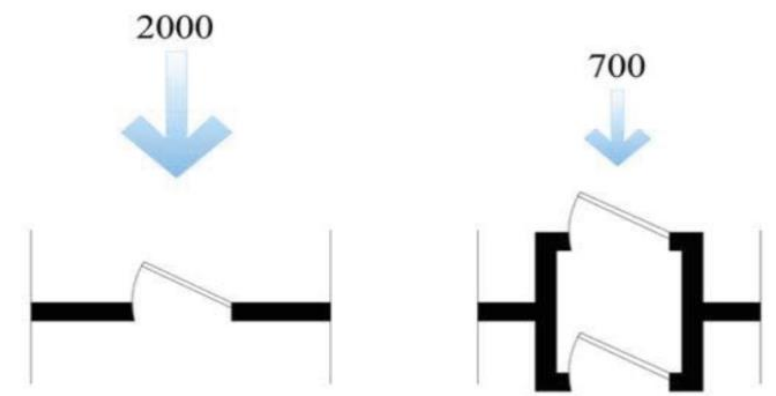

Figure 4. the numbers indicate that the amount of cubic feet of air entering the building is the result of opening the door once [21].

\section{Using vestibule at the entrance of the building}

Under normal winter conditions, while doors and windows are closed, air infiltration will increase the building's thermal load by 1.3 times. Heat loss through air penetration will reach about $75 \%$ of the total thermal load of the building. Vestibule design in the part of the building that faces the north wind, will also be of high value. Although, an attempt must be made not to put the entrance door in this part of the building [12].

\section{Building shell design arrangements}

Shell is also an efficient component in design and faces three general methods with buildings shells to achieve proper design with climatic principles:

1. Shell as the separator of building from the outside climatic conditions through thermal resistance (insulation).

2. Shell as thermal mass (delaying the conduction of heat through the body of the building) 
3. Shell as the storage and distributor of heat in the building [22].

\section{Using double-glazed windows}

Windows are more vulnerable to unwanted heat transfer than any other element in the building shell. The thermal resistance of normal glass is much less than that of insulated walls. The thermal resistance of double-glazed windows is $\mathbf{1 . 2}$ times that of singleglazed windows [12]. Double-glazed windows help to reduce energy consumption by $37 \%$.

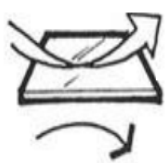

wind with the speed of $15 \mathrm{mph}$ glass with the thickness of $1 / 8(0.3 \mathrm{~cm})$ stationary air
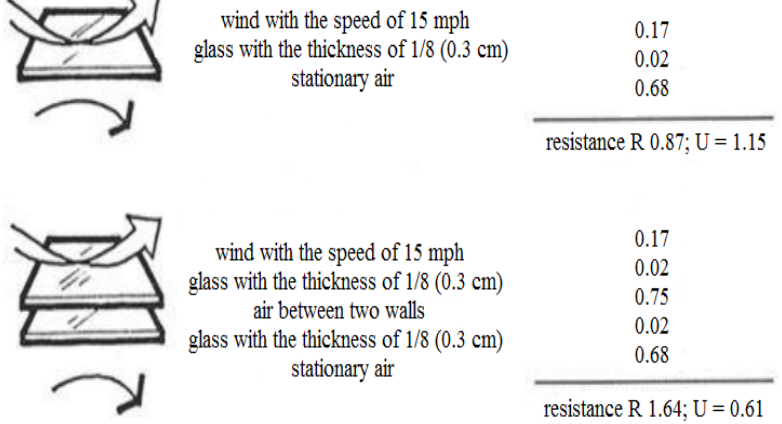

wind with the speed of $15 \mathrm{mph}$ glass with the thickness of $1 / 8(0.3 \mathrm{~cm})$ air between two walls glass with the thickness of $1 / 8(0.3 \mathrm{~cm})$ stationary air

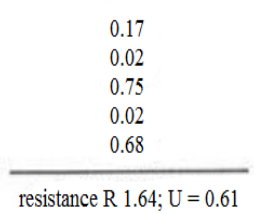

Figure 5. Double-glazed window [29]

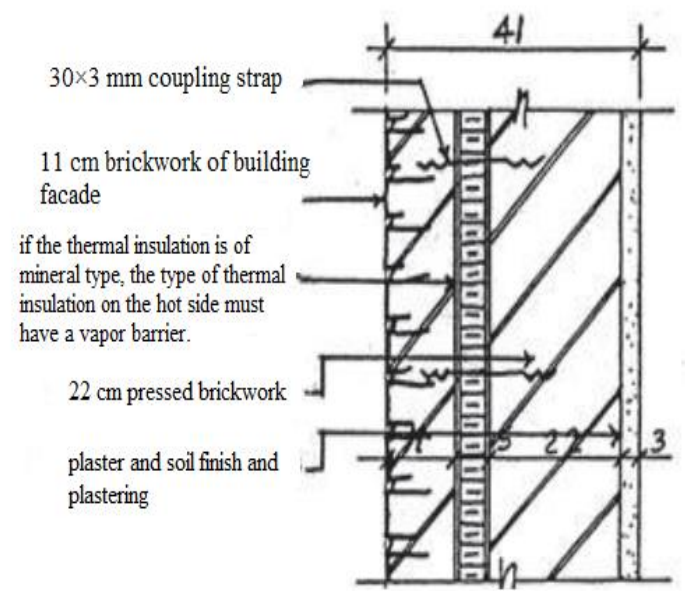

Figure 6. The details of double-glazed wall with 11 $\mathrm{cm}$ brickwork façade

The insulation of exterior walls of the building and the proper design of openings

To achieve the goals of sustainable architecture and the design of building's shells with the climatic approach, observing the following points can be effective:

1. The direction of the building is one of the serious issues for using sunlight in winter in cold and mountainous climates. To reduce energy consumption, the design based on inactive system is influential [23].
2. Using double-glazed or multiple-glazed walls with an empty space between two shells, is a method to avoid heat loss [23].

3. Using proper materials with high capacity and thermal insulation is one of the solutions that can be used to prevent outer cold air [23].

4. Maintaining heat by placing thermal insulation on the exterior shell of the building.

5. To prevent evaporative freezing in the building shell in cold and mountainous climate, vapor barrier needs to be installed in the warm side of the building shell insulation [24].

6. Minimizing the number and area of openings and using materials with lower heat transfer coefficient for window frames.

7. Using night insulation for windows (night insulation is a thick screen that is pulled into the interior wall of windows during the night to prevent heat dissipation). Thick screens help reduce heat transfer by 4 to 8 percent, thus reducing energy consumption [25].

\begin{tabular}{|l|l|l|}
\hline $\begin{array}{l}\text { Building } \\
\text { component }\end{array}$ & Function & Usage \\
\hline Thick screen & $\begin{array}{l}\text { 1. Reducing the speed of } \\
\text { indoor and outdoor heat } \\
\text { exchange } \\
\text { 2. Camouflage inside at night } \\
\text { 3. Reducing natural light }\end{array}$ & $\begin{array}{l}\text { For rooms } \\
\text { cold nights }\end{array}$ \\
\hline
\end{tabular}

Source: Razjouyan [28]

8. Building shell should not cast a shadow on itself (progress and regression should not be in the plan)

9. Using plants in the greenhouse space and its combination with building facade to absorb the heat of the sun from the outer space into indoor space [26].

10. Adding a new layer of materials in the details around entrances and windows and reducing the penetration of cold air and lowering energy consumption [27].

11. The exterior facade of building in the cold climate should be covered with dark colors. Therefore, it will absorb more thermal energy [28]. The following table shows the percentage of the thermal absorption of various kinds of colors:

\begin{tabular}{|l|l|}
\hline Color & $\begin{array}{l}\text { The percentage of thermal } \\
\text { absorption }\end{array}$ \\
\hline Black & $\begin{array}{l}\text { Percentage of thermal } \\
\text { absorption capacity }\end{array}$ \\
\hline Brown, green, and red & $92 \%$ \\
\hline Yellow & $73 \%$ \\
\hline Light beige and white & $60 \%$ \\
\hline Metalic (dark metalic) & $40 \%$ \\
\hline Metalic (bright metalic) & $52 \%$ \\
\hline Completely bright metalic & $40 \%$ \\
\hline Rouhani M, [30]. &
\end{tabular}


12. Using photovoltaic cells in building facade and roof and its combination with building structure is a method to provide sufficient heat in the building from solar energy [29] Observing the mentioned items will reduce energy loss by $29 \&$ in the walls, and $14 \%$ in the openings, thus reducing the consumption of fossil fuels [27].

\section{Green roof}

The contemporary method of roof greenery, known as green roof, represents a space where grass and plants are planted at a shallower depth of soil. Green roof is a space with a vegetation cover that is structurally combined with any man-made structure. The word 'roof' in this term is used to refer to any continuous surface whether with open or closed walls that has been designed for protecting residents [35]. Green roof system is a branch of sustainable architecture with many economical goals including increasing insulation by $25 \%$ and saving energy [26].

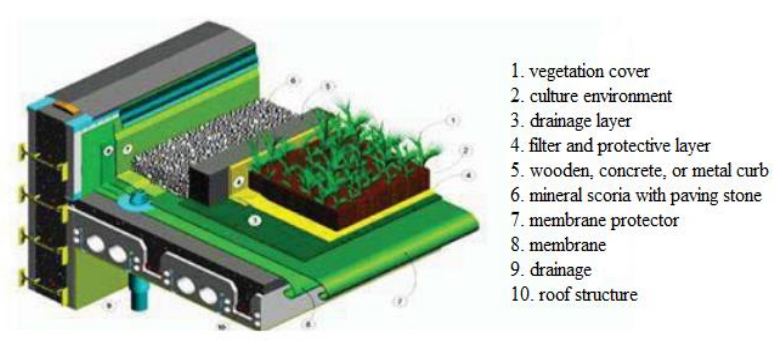

Figure 7. the constituting elements of green roof [30].

Using the space under sloping roof as a storage space between indoor and outdoor air

The attic floor must be well insulated to prevent heat loss from the attic and also to prevent roof heating which melts snow. Due to the heat absorption from the south side of sloping roof, the temperature of this room is also increased which causes snow to melt on the north side of the roof and also creates an ice dam. This room should be properly ventilated to prevent this as well as perspiration. The protrusion of roof edge and holes under the arch are suitable for ventilation and for keeping attic space cool [12]. The thermal insulation of roof reduces heat loss by $26 \%$, and so cuts down fossil fuels consumption [25].

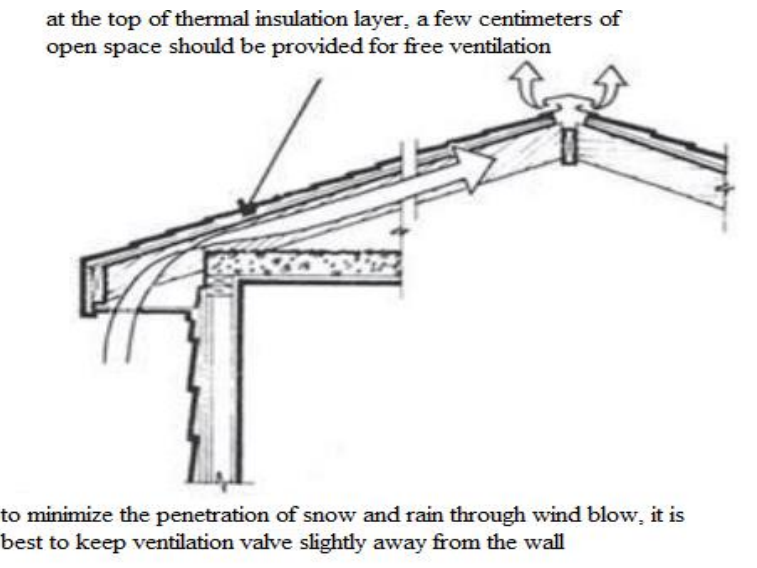

Figure 8. the ventilation and cooling of attic space by the protrusion of roof edge and holes under the $\operatorname{arch}[12]$.

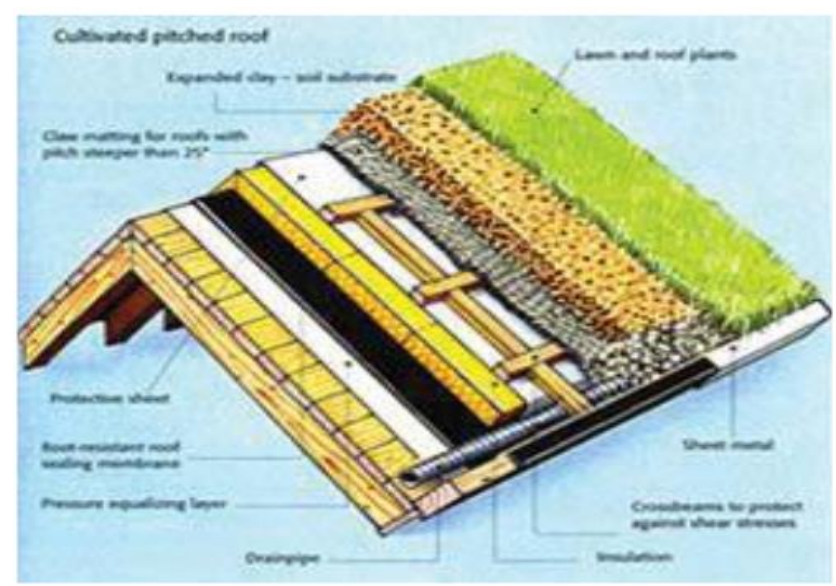

Figure 9. The details of sloping green roof [22].

\section{Mechanical heating system}

Underfloor heating system saves energy by $25 \%$ to $30 \%$ compared with conventional heating systems like radiator, or fan coil. The reasons for this are extremely large radiation levels (equal to the area of heated space), low water temperature circulating in underfloor heating system (between $35 \%$ to $50 \%{ }^{\circ} \mathrm{C}$ ), low heat exchange between floor and cold walls, even distribution of heat throughout the surface and space, and avoiding problems with radiator including its blackness, clogging, decay and finally problems related to repairing and maintaining it. Using this thermal method, warm weather in the environment will be very desirable and uniform because hot air is lighter than cold air and heat is always transferred from bottom to top. Thus, it would be better to heat the ambient air from lower level (floor) [29]. 

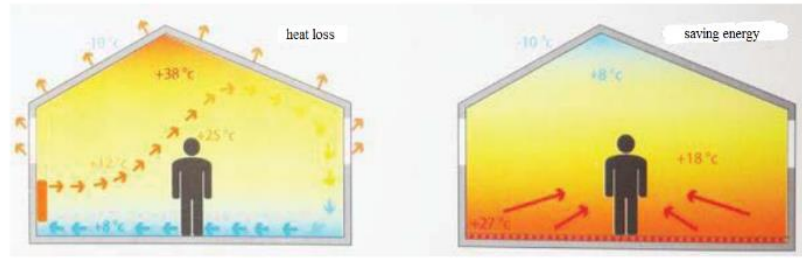

Figure 10. proper and ideal mode in underfloor heating system and improper mode in radiator and fan coil heating systems

\section{Wind energy}

Using wind energy in high-rise buildings has higher efficiency than low buildings due to the considerable height of these constructions and the high speed and intensity of wind. Using this energy in the natural ventilation of high-rise buildings (atrium) and also in the generation of electricity by means of wind turbines, is among the strategies used in these buildings for sustainability [16].

\begin{tabular}{|c|c|c|}
\hline 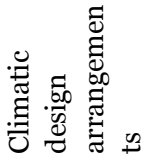 & Descriptions & $\begin{array}{l}\text { The level of reduced } \\
\text { energy consumption }\end{array}$ \\
\hline 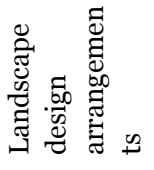 & $\begin{array}{l}\text { - Using plants next } \\
\text { to the exterior walls } \\
\text { of buildings }\end{array}$ & $\begin{array}{l}\text { - the reduced } \\
\text { consumption of heating } \\
\text { by } 25 \% \text { and of cooling by } \\
50 \%\end{array}$ \\
\hline 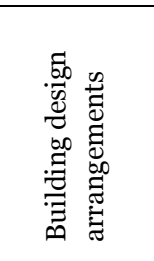 & $\begin{array}{l}\text { - locating building } \\
\text { deep in the ground } \\
\text { - using vestibule in } \\
\text { entrance } \\
\text { - designing semi- } \\
\text { protected areas } \\
\text { outside building }\end{array}$ & $\begin{array}{l}\text { - reduced heat loss by } 35 \% \\
\text { - reduced heat loss by } 15 \% \\
\text { through air permeation } \\
\text { - reduced energy } \\
\text { consumption by } 20 \%\end{array}$ \\
\hline 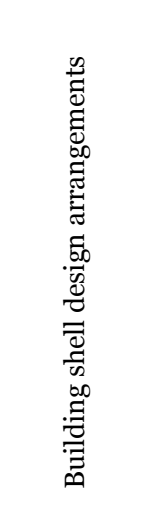 & $\begin{array}{l}\text { - using double- } \\
\text { glazed windows } \\
\text { - insulating the } \\
\text { exterior walls of } \\
\text { buildings } \\
\text { - insulating roofs } \\
\text { - green roof system } \\
\text { - proper design of } \\
\text { openings } \\
\text { - indoor canopies }\end{array}$ & $\begin{array}{l}\text { - reduced heat loss by } 37 \% \\
\text { compared with single- } \\
\text { glazed windows } \\
\text { - reduced energy } \\
\text { consumption by } 29 \% \\
\text { - reduced energy } \\
\text { consumption by } 26 \% \\
\text { - increased insulation } \\
\text { level by } 25 \% \\
\text { - reduced energy } \\
\text { consumption by } 14 \% \\
\text { - reduced sunlight by } 20 \% \\
\text { to } 25 \% \text { and reduced heat } \\
\text { transfer by } 4 \% \text { to } 8 \%\end{array}$ \\
\hline 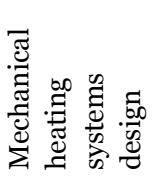 & $\begin{array}{l}\text { - underfloor } \\
\text { heating system }\end{array}$ & $\begin{array}{l}\text { - reduced energy } \\
\text { consumption by } 30 \% \\
\text { compared with other } \\
\text { mechanical systems }\end{array}$ \\
\hline
\end{tabular}

Table 6. Climatic design arrangements and proper mechanical system to reduce energy consumption. (the analysis and processing of the research by author)

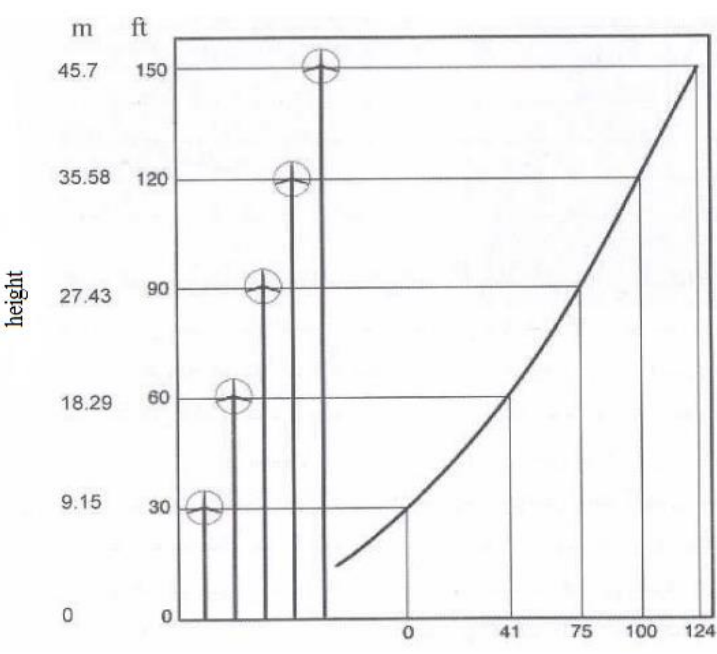

Chart 1. The increased wind density in different heights. Source [30].

\section{DATA ANALYSIS AND CONCLUSION}

This study attempted to analyze the effective components of sustainable architecture in the design of high-rise buildings to reduce energy consumption in Tabriz so that it can deal with the effect of the above-mentioned models on reducing fossil fuels consumption and environment sustainability. The following table shows sustainability models in the design of high-rise buildings in cold and dry climate and the effect of these models on reducing fossil fuels consumption for heating buildings.

Thus, today, considering the air pollution in cities and environmental issues resulting from using non-renewable energy resources, the design of highrise buildings should be reconsidered. Given the data mentioned in Table 6 , it could be found that by observing sustainability models in the design of towering buildings in cold climate, we can:

- Do modeling for high-rise spaces to achieve climate-friendly architectural concepts

- Save energy for heating spaces by $66 \%$

- Save energy for cooling spaces by $37.5 \%$.

\section{Suggestions}

The following suggestion are, thus, provided in addition to those mentioned in the above table, to re-examine high-rise buildings design and to save more energy in consuming fossil fuels for heating buildings in winter:

1. Using domestic, accessible, environmentally-friendly materials

2. Designing a narrow and elongated form of the building along the east-west axis 
3. Designing openings in the southern facade of the building to use sunlight in winter

4. Blocking and insulating the windward and cold side of building in winter, and using coniferous trees against cold winds sides

5. Minimizing openings in eastern and western

6. Using south porches as canopies against sunlight in summer

7. Working out the depth of canopy given the angle of radiation of the sun in winter and summer

8. Using greenhouse space in the southern side of building

9. Locating main spaces like bedroom, living room, and dining room in the southern side

The presence of corridors in the northern side of the building as the intermediate space between main indoor and outdoor spaces.

\section{DECLARATIONS}

\section{Authors' contribution}

All the authors contributed equally to the work presented.

\section{Competing interests}

The authors declare that there is no competing interests.

\section{REFERENCES}

[1] Mahmoudi, M (2009). Developing Housing in Keeping with Sustainable Development (1st edition). Tehran: Tehran University Publications. Journal of Fine Arts, 14(14), 71-82.

[2] Zakir Hagigi, K (2011). The Analysis of the Different Dimensions of Achieving Sustainable Housing. Proceedings of the Second National Conference on Sustainable Architecture, Hamedan, 1, 1.

[3] Khiavi A and Lahroudi M (2010). The Dynamic Modelling of Building Heating. Payam Ark Quarterly, 24, 52.

[4] Gobadian V, Gobadian T, Gobadian N and Godsi M (20072008). Executive Design: Three Kinds of Sustainable Solar Houses in Tehran. Journal of Architecture and Construction, (15), 30 .

[5] shaghaghi,sh (2006). The relationship between sustainable development and climatic design of buildings in cold and dry areas, Environmental science and technology

[6] Sajjadi Gaemmagami P S, Pourdeyhami S, Zarghami E (2010). The Principles of Social Sustainability in Housing Developments. Journal of Soffeh, (51), 76.

[7] Singari M (2007). Describing the Structure of Sustainable Architecture and Presenting its Practical Strategies in Tabriz. Research Project of the Architecture Department, Research Branch of Islamic Azad University, 3-6.

[8] Memarian G H (2008). Familiarizing with Iranian Residential Architecture: Introverted Typology (5th edition). Tehran: Soroush Knowledge Cultural Institute.
[9] Moeini M (2008). The Study of the Formation Process of Housing in Nomadic Communities: Case Study of Golafshan village in Semirom County, Isfahan. Journal of Fine Arts, (33), 47-56.

[10] Pourdeyhami S (2001). Experiences of Housing Formation Process in Western Countries. Journal of Architecture and Culture, (9). 54.

[11] Hataminejad H, Seifoddini F, and Mireh M. (2006). The Analysis of Informal Housing Indices: A Case Study in Sheikhabad Neighborhood, Qom. Geographical Research Quarterly, (58), 133.

[12] Watson D (1983). Climatic Design: Theoretical and Executive Principles of Using Energy in Building (V. Gobadian, \& M. Feizmahdavi, Trans.). Tehran, Iran: Tehran University Publishing (Original work published 1983).

[13] Hariri Rezai M T, Habibi M, Khakpour M \& Fayyaz R (2004). The National Housing Regulations in Iran: Topic 19 - Saving Energy (5th edition). Tehran: Tosseh Iran Publishing.

[14] Pourdeyhami S (1999). Climate-friendly Construction. Journal of Soffeh, 9(28), 69.

[15] Nagizadeh M (2000). The Qualitative Features of Desirable Building (the Basics of Design and the Ways to Achieve it). The Journal of Soffeh, 10(31), 94.

[16] Golabchi M (2014). The Basics of Designing High-rise Buildings. Tehran: Tehran University Publications.

[17] Kasmayi M (2005) Climate and Architecture (3rd edition). Isfahan: Khak Publications.

[18] Shagagi S, \& Mofidi SM (2008). The Relationship between Sustainable Development and Climatic Design of Buildings in Cold and Dry Regions: Case Study in Tabriz. Journal of Environmental Science and Technology, 10(3), 105-120.

[19] Afsar B \& Salehi S (2011). Landscaping to Save and Maintain Energy. Proceedings of the Second National Conference on Sustainable Architecture, Hamedan, 27, 12-4.

[20] Bideli M \& Qajarbeigi M M (2011). Traditional Iranian Architecture: A Manifestation of Sustainable Architecture. Proceedings of the Second National Conference on Sustainable Architecture, Hamedan, 58, 6.

[21] Lanker N (2006). Heating, Colling, Lightning: Design Strategies for Architects (M. A. Keynejad, \& R. Azari, Trans.). Tabriz, Iran: Tabriz Islamic Art University Publications.

[22] Abolhasani, S M and Razazi, M R (2007). New algorithm for determining the status of point in convex polygons. $13^{\text {th }}$ national conference held by Iran's association of computer, Kish, Persian Guld, Iran, pp.1-4

[23] Borjsefidi N (2009). A New Look at the Use of Building Shells from Climatic to Aesthetic Bodies. Journal of Architecture and Culture, (38). 15

[24] Razjouyan M (2009). Comfort due to Climate-Friendly Architecture (2nd edition). Tehran: Shahid Beheshti Publication.

[25] Goudarzi Soroush M M \& Morseli M (2011). The Analysis of the Elements of Sustainable Architecture in Traditional Architecture of Cold Climate (Hamedan) and How to Use these Elements in the Current Architecture of the Country. Proceedings of the Second National Conference on Sustainable Architecture, Hamedan, 32, 5.

[26] Ahmadi F (2011). The Role of Architectural Design in Reducing Building's Fuel Consumption. Proceedings of the Second National Conference on Sustainable Architecture, Hamedan, 48, 3 .

[27] Feizi M \& Benayi M (2009). Green Shells. Iranian Architecture Quarterly, 9-10(36-37), 124. 
[28] Keshtkar Galati AR \& Ansari M, Nazi Dizaji S (2010). Developing Green Roof System in Accordance with Sustainable Development. Journal of Hoviat Shahr, 4(6), $15-28$.

[29] Alavi, AS (2011). Green Roof: A Strategy Towards Sustainable Architecture. Proceedings of the Second
National Conference on Sustainable Architecture, Hamedan, 92, 5 .

[30] Rouhani M (2000). Heating System in the Bedroom Floor. Journal of Installation Industry, (12), 26. 